\title{
Extracellular signal-regulated kinase 8-mediated NF-kB activation increases sensitivity of human lung cancer cells to arsenic trioxide
}

\author{
Dan-Dan Wu $\mathbf{u}^{1, *}$, Andy T.Y. Lau ${ }^{1, *}$, Fei-Yuan Yu${ }^{1}$, Na-Li Cai ${ }^{1}$, Li-Juan Dai ${ }^{1}$, Myoung Ok \\ $\mathrm{Kim}^{2}$, Dong-Yan $\mathrm{Jin}^{3}$ and Yan-Ming $X \mathbf{u}^{1}$ \\ ${ }^{1}$ Laboratory of Cancer Biology and Epigenetics, Department of Cell Biology and Genetics, Shantou University Medical College, \\ Shantou, Guangdong, P.R. China \\ ${ }^{2}$ Department of Animal Science, Kyungpook National University, Republic of Korea \\ ${ }^{3}$ School of Biomedical Sciences, Li Ka Shing Faculty of Medicine, The University of Hong Kong, Hong Kong, P.R. China \\ *These authors contributed equally to this work
}

Correspondence to: Yan-Ming Xu, email: amyymxu@stu.edu.cn

Keywords: arsenic trioxide, ERK8, IKBa, MAPK15, nuclear factor-kappaB

Received: November 16, $2016 \quad$ Accepted: April 03, $2017 \quad$ Published: April 13, 2017

Copyright: Wu et al. This is an open-access article distributed under the terms of the Creative Commons Attribution License 3.0 (CC BY

3.0), which permits unrestricted use, distribution, and reproduction in any medium, provided the original author and source are credited.

\section{ABSTRACT}

Extracellular signal-regulated kinase 8 (ERK8), also known as mitogen-activated protein kinase 15 (MAPK15), is the most recently identified protein kinase of the ERK family members and yet the least has been studied so far. Here, we report that ERK8 is highly expressed in several human lung cancer cell lines and is positively correlated with their sensitivities to the anti-cancer drug arsenic trioxide $\left(\mathrm{As}_{2} \mathrm{O}_{3}\right)$. $\mathrm{As}_{2} \mathrm{O}_{3}$ at physiologically relevant concentrations $(5-20 \mu \mathrm{M})$ potently stimulates the phosphorylation of ERK8 at Thr $^{175}$ and $\mathrm{Tyr}^{177}$ within the TEY motif in the kinase domain, leading to its activation. Interestingly, activated ERK8 interacts and directly phosphorylates IkappaBalpha (IKBa) at Ser ${ }^{32}$ and $\mathrm{Ser}^{36}$, resulting in IKBa degradation. This in turn promotes nuclear factor-kappaB (NF-kB) p65 nuclear translocation and chromatin-binding, as well as the subsequent induction and activation of proteins involved in apoptosis. We also show that stable short-hairpin RNA-specific knockdown of endogenous ERK8 or inhibition of NF-KB activity by NF-KB inhibitor in high ERK8 expressing lung cancer $\mathrm{H1299}$ cells blunted the $\mathrm{As}_{2} \mathrm{O}_{3}$-induced NF-KB activation and cytotoxicity towards these cells, indicating the critical role of ERK8 and NF-KB in mediating the $\mathrm{As}_{2} \mathrm{O}_{3}$ effects. Taken together, our findings suggest for the first time a regulatory paradigm of NF-KB activation by ERK8 upon $\mathrm{As}_{2} \mathrm{O}_{3}$ treatment in human lung cancer cells; and implicate a potential therapeutic advantage of $\mathrm{As}_{2} \mathrm{O}_{3}$ that might gain more selective killing of cancer cells with high ERK8 expression.

\section{INTRODUCTION}

Human ERK8 (alias MAPK15), located at 8q24.3, is the most recently identified member of the ERK family [1]. Over the past decades, despite the fact that in-depth investigations have been done on typical ERKs (ERK1 and 2), the functions of ERK8 remain relatively understudied, in which there are still a lot of unanswered questions for its cellular function. ERK8 resembles ERK1, ERK2, and ERK5 that possesses a Thr-Glu-Tyr motif in the activation loop [1]. ERK8 has been considered as an atypical MAPK partly because it contains the long carboxyl-terminal domain that regulating its activity, cellular localization and function [1-3]. Furthermore, ERK8 is regulated by auto-phosphorylation and no specific upstream activating kinase has been identified so far [1, 4, 5]. Earlier studies from several research groups have shown that ERK8 activity can be stimulated by serum, DNA damage, and human oncogenes such as RET/PTC3 (an active form of the $R E T$ proto-oncogene) [1, 6, 7]. Moreover, ERK8 has recently been shown to increase tumorigenesis in human colon cancer cells by activating c-jun and in gastric cancer cells by stabilizing c-Jun $[8,9]$. Besides, ERK8 is involved in maintaining genome stability as well as autophagy $[10,11]$. Yet, it is still unclear whether ERK8 acts as a proto-oncogene or tumor suppressor. However, it should 
be noted that protein expressed in one cell type might actually function differently in another, leading to diverse phenotypes. Therefore, no unified functions of ERK8 can be drawn conclusively at present.

Arsenic trioxide $\left(\mathrm{As}_{2} \mathrm{O}_{3}\right)$, a traditional Chinese medicine, inhibits growth and promotes apoptosis in many different cancer cell types. It has been proven especially to be highly effective against hematologic malignancies, such as acute promyelocytic leukemia (APL) [12, 13]. Moreover, promising preclinical activity of $\mathrm{As}_{2} \mathrm{O}_{3}$ against malignancies other than APL was noted, such as myeloid leukemia, lymphoma, lymphocytic leukemia, and solid tumor cell lines of prostate, cervix, bladder, ovary, colon, stomach, and esophagus [12]. Lung cancers are malignant tumors with high incidences in China and worldwide [14] and characterized with high mortality because of the development of acquired resistance to chemotherapy [15]. Although recent studies have shed light on the potential of $\mathrm{As}_{2} \mathrm{O}_{3}$ against human lung cancers [16-21], however, there are still missing links to be explored.

In this study, we provide evidence to show that ERK8 is highly expressed in several human lung cancer cell lines. Remarkably, we report for the first time that $\mathrm{As}_{2} \mathrm{O}_{3}$ at physiologically relevant concentrations (effective in as low as $\sim 5 \mu \mathrm{M}$ ) induces the phosphorylation of ERK8 and activated ERK8 subsequently promotes the phosphorylation and degradation of $\mathrm{I} \kappa \mathrm{B} \alpha$, which leads to the activation of NF- $\kappa \mathrm{B}$ and lung cancer cell apoptosis. The pro-apoptotic role of ERK8 and NF- $\kappa \mathrm{B}$ played in $\mathrm{As}_{2} \mathrm{O}_{3}$ cytotoxicity has been supported by the fact that short-hairpin RNA-specific knockdown of ERK8 or inhibition of $N F-\kappa B$ activity by $N F-\kappa B$ inhibitor in high ERK8-expressing human lung cancer H1299 cells blunted the $\mathrm{As}_{2} \mathrm{O}_{3}$-induced $\mathrm{NF}-\kappa \mathrm{B}$ activation and cytotoxicity towards these cells, indicating that both ERK8 and NF- $\kappa \mathrm{B}$ are critical players in mediating the effects of $\mathrm{As}_{2} \mathrm{O}_{3}$. Taken together, our findings establish a novel regulatory circuit of NF- $\kappa$ B activation by ERK8 upon $\mathrm{As}_{2} \mathrm{O}_{3}$ treatment, and implicate the potential of $\mathrm{As}_{2} \mathrm{O}_{3}$ in targeting lung cancers with high ERK8 expression.

\section{RESULTS}

\section{$\mathrm{As}_{2} \mathrm{O}_{3}$ induces the phosphorylation of ERK8}

Our group has been investigating novel functions of oncokinases and their downstream substrates as potential signaling axis/molecular targets for cancer intervention. Here, we focused on novel functions and signaling cascade mediated by ERK8. Previously, ERK8 has been shown to be phosphorylated and activated by serum and growth factors such as epidermal growth factor (EGF) and increased tumorigenesis of human colon cancer [8]. However, other stimuli that would lead to its activation is unclear and the involvement of ERK8 in ROS stress/ redox signaling is largely unexplored. Among the ROS- inducing drugs, we are particularly keen on $\mathrm{As}_{2} \mathrm{O}_{3}$ as it is a well-known anti-cancer therapeutic agent with promising efficacy on hematologic malignancies such as APL. To determine whether ERK8 can be activated by $\mathrm{As}_{2} \mathrm{O}_{3}$, we transfect Xpress-ERK8 in HEK293T cells and they were subsequently exposed to $\mathrm{As}_{2} \mathrm{O}_{3}$. As the phosphorylation of ERK8 at $\mathrm{Thr}^{175}$ and $\mathrm{Tyr}^{177}$ signifies its kinase activation status and therefore we detected the levels of p-ERK8 at $\mathrm{Thr}^{175}$ and $\mathrm{Tyr}^{177}$ upon $\mathrm{As}_{2} \mathrm{O}_{3}$ treatment in these cells by western blot analyses. Surprisingly, from the results, it can be seen that the phosphorylation of ERK8 is increased by $\mathrm{As}_{2} \mathrm{O}_{3}$ treatment in a dose- and time-dependent manner, suggesting that ERK8 can be activated by $\mathrm{As}_{2} \mathrm{O}_{3}$ and that ERK8 may mediate the cellular effects of $\mathrm{As}_{2} \mathrm{O}_{3}$ (Figure 1A-1C). This prompts us further to delineate the possible relationship of $\mathrm{As}_{2} \mathrm{O}_{3}$ and ERK8 and the downstream targets.

\section{IKB $\alpha$ as a novel substrate of ERK8}

To date, knowledge about the cellular physiological protein substrate(s) of ERK8 is limited. Previous studies have shown that c-Jun is an ERK8 substrate and related to colon and gastric cancer development $[8,9]$. For this reason, we sought to discover novel ERK8 substrates and we are particular keen on redox signaling pathways since we found that ERK8 can be activated by the oxidant $\mathrm{As}_{2} \mathrm{O}_{3}$. To identify novel substrates of ERK8, we first expressed and purified active His-tagged ERK8 and perform in vitro kinase assay using a list of potential substrates available in our laboratory. Remarkably, among these substrates, we found that $\mathrm{I} \kappa \mathrm{B} \alpha$ can be robustly phosphorylated by ERK 8 at $\mathrm{Ser}^{32}$ and $\mathrm{Ser}^{36}$ as determined by western blot analyses (Figure 2A and 2B), but not the ERK8 K42R kinase-dead mutant (Figure 2C).

To determine whether ERK 8 and $\mathrm{I} \kappa \mathrm{B} \alpha$ interact each other, plasmids encoding $\mathrm{HA}-\mathrm{I} \kappa \mathrm{B} \alpha$ and Xpress-ERK8 were cotransfected into HEK293T cells. I $\kappa \mathrm{B} \alpha$ proteins were immunoprecipitated with anti-HA agarose beads and subjected to western blot analyses using anti-Xpress antibody. ERK8 was confirmed to interact with $\mathrm{I} \kappa \mathrm{B} \alpha$ ex vivo (Figure 2D). From the results, we reported for the first time that I $\mathrm{B} \alpha$ is a novel substrate of ERK 8 and the likelihood of ERK8 in regulating NF- $\mathrm{B}$ pathway.

\section{ERK8 promotes the phosphorylation and degradation of IкB $\alpha$}

Among the redox sensitive transcription factors, $\mathrm{NF}-\kappa \mathrm{B}$ is regulated by its inhibitor I $\mathrm{B} \alpha$ which sequesters $\mathrm{NF}-\kappa \mathrm{B}$ from entering the nucleus. Upon stimulus, phosphorylation of IкB $\alpha$ at $\mathrm{Ser}^{32}$ and $\mathrm{Ser}^{36}$ would lead to

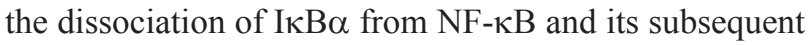
ubiquitin-proteasomal degradation; as a result, NF- $\mathrm{\kappa B}$ is translocated from the cytosol into nucleus and activates NF-кB-dependent gene expression [22]. To investigate 
the cellular physiological role of ERK8 in modulation of NF- $\mathrm{BB}$ pathway, first, we transfected Xpress-ERK8 into HEK293T cells and they were subsequently treated with $5 \mu \mathrm{M} \mathrm{As}_{2} \mathrm{O}_{3}$ for $4 \mathrm{~h}$. From the western blot results, we observed that ectopically-expressed ERK8 can be activated by $\mathrm{As}_{2} \mathrm{O}_{3}$ treatment and the p-ERK8 levels positively correlate to the amount of the ERK8 plasmid transfected (Figure 3A). Moreover, if $\mathrm{I} \kappa \mathrm{B} \alpha$ is a physiological substrate of ERK8 and ERK8 would catalyze the phosphorylation of $\mathrm{I} \kappa \mathrm{B} \alpha$ at $\mathrm{Ser}^{32} / \mathrm{Ser}^{36}$ in cells, then ERK8 should also presumably promote the degradation of $\mathrm{I} \kappa \mathrm{B} \alpha$. As expected, when we transfect an increasing amount (1 to $6 \mu \mathrm{g}$ ) of Xpress-ERK8 expression plasmid into cells and subsequently dosed them with $5 \mu \mathrm{M}$
$\mathrm{As}_{2} \mathrm{O}_{3}$, the expression level of endogenous I $\mathrm{B} \alpha \alpha$ declined accordingly (Figure 3A). To correlate if the decline of $\mathrm{I} \kappa \mathrm{B} \alpha$ level is due to phosphorylation, we perform similar experiments and also monitor the level of $\mathrm{p}-\mathrm{I} \kappa \mathrm{B} \alpha$ at $\mathrm{Ser}^{32} / \mathrm{Ser}^{36}$. From the results, it can be seen that there is an obvious enhancement of phosphorylation of $\mathrm{I} \kappa \mathrm{B} \alpha$ at $\mathrm{Ser}^{32} / \mathrm{Ser}^{36}$ in ERK8 transfected cells with $\mathrm{As}_{2} \mathrm{O}_{3}$ treatment (Figure 3B, lane 4). Although there is also elevation of the $\mathrm{p}-\mathrm{I} \kappa \mathrm{B} \alpha$ level in $\mathrm{As}_{2} \mathrm{O}_{3}$-treated cells (Figure 3B, lane 3 ), however, the protein level of $\mathrm{I} \kappa \mathrm{B} \alpha$ declined more dramatically in Xpress-ERK8 transfected cells with $\mathrm{As}_{2} \mathrm{O}_{3}$ treatment (Figure 3B, lane 4). The ratio of p-I $\kappa \mathrm{B} \alpha / \mathrm{I} \kappa \mathrm{B} \alpha$ has the highest value in Xpress-ERK8 transfected cells with $\mathrm{As}_{2} \mathrm{O}_{3}$ treatment, reflecting that endogenous $\mathrm{I} \kappa \mathrm{B} \alpha$

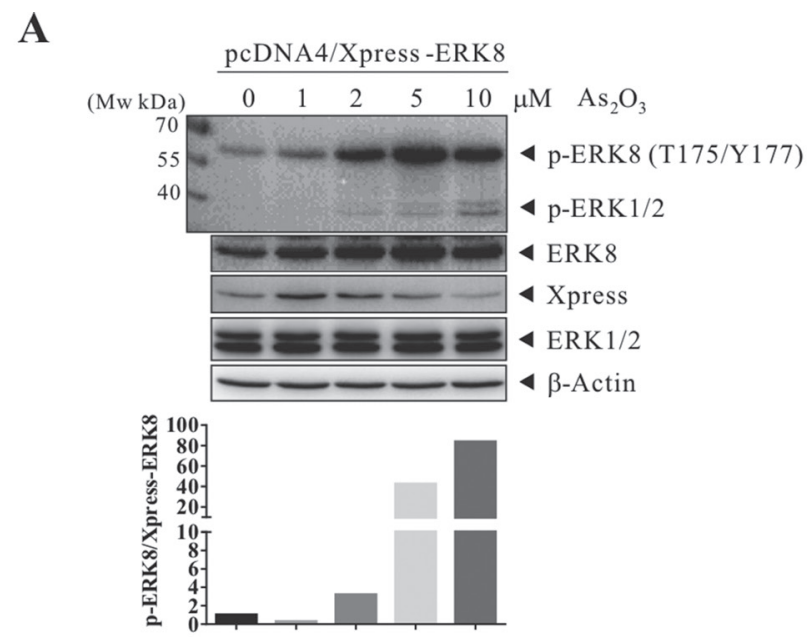

B

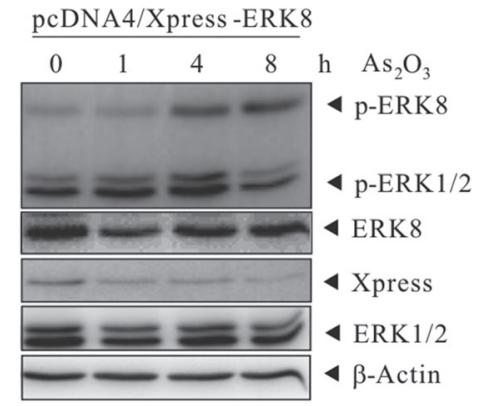

C

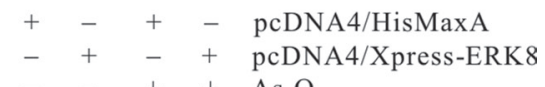

$-\quad+\quad+\mathrm{As}_{2} \mathrm{O}_{3}$

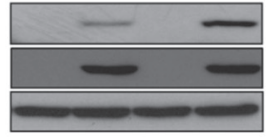

4 p-ERK8

4 Xpress

$\varangle$-Actin
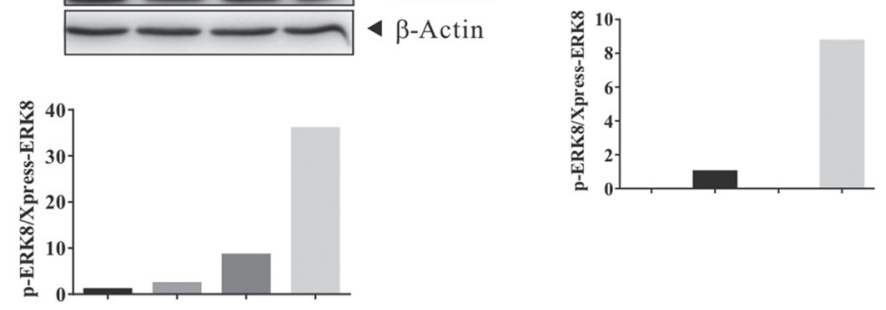

Figure 1: Activation of ERK8 by $\mathrm{As}_{2} \mathrm{O}_{3}$ in a dose and time-dependent manner in Xpress-ERK8 transfected cells. HEK293T cells were transfected with pcDNA4/HisMaxA control or pcDNA4/Xpress-ERK8 expression plasmids $(6 \mu \mathrm{g})$. At $24 \mathrm{~h}$ posttransfection, they were cultured in serum-free medium for $24 \mathrm{~h}$, after which they were sham exposed or exposed to $\mathrm{As}_{2} \mathrm{O}_{3}$ and monitored. (A) 1 to $10 \mu \mathrm{M} \mathrm{As}_{2} \mathrm{O}_{3}$ for $4 \mathrm{~h}$; (B) $5 \mu \mathrm{M} \mathrm{As}_{2} \mathrm{O}_{3}$ for 1 to $8 \mathrm{~h}$; and (C) $5 \mu \mathrm{M} \mathrm{As}_{2} \mathrm{O}_{3}$ for $4 \mathrm{~h}$. Cells were lysed, and protein extracts were subjected to SDS-PAGE followed by immunobloting using antibodies against p-ERK8 $\left(\mathrm{Thr}^{175} / \mathrm{Tyr}^{177}\right)$. After development, the membranes were stripped and reprobed with regular antibodies against ERK8, Xpress, ERK1/2, and $\beta$-actin to monitor the total level of ERK8, ERK1/2, and loading difference, respectively. The data are representative of three independent experiments. 
protein level is rapidly declined. To further substantiate the notion that the decline of $I \kappa \mathrm{B} \alpha$ protein level is due to its proteasomal degradation, we pretreated these cells with the proteasome inhibitor MG132 before exposure to $\mathrm{As}_{2} \mathrm{O}_{3}$. From the results, treatment of MG132 prior to $\mathrm{As}_{2} \mathrm{O}_{3}$ treatment prevented the decline of $\mathrm{I} \kappa \mathrm{B} \alpha$ upon $\mathrm{As}_{2} \mathrm{O}_{3}$ treatment (compare lane 2 to lane 3 in Figure 3C). To determine whether I $\kappa \mathrm{B} \alpha$ degradation would lead to enhanced NF- $\kappa B$ activity, we performed NF- $\kappa B$ luciferase assay by cotransfecting the $5 \times \kappa \mathrm{B}$ firefly luciferase reporter with Xpress-ERK8 expression plasmid in NIH/3T3 cells and then challenged the cells with $5 \mu \mathrm{M} \mathrm{As} \mathrm{O}_{3}$ for $4 \mathrm{~h}$. Our results indicate that $\mathrm{As}_{2} \mathrm{O}_{3}$ can synergize ERK8 in promotion of NF- $\kappa \mathrm{B}$ activity (Figure $3 \mathrm{D}$ ).

\section{ERK8 promotes the phosphorylation and degradation of I $\mathrm{I} B \alpha$, as well as nuclear translocation of NF- $\mathrm{KB}$ in human lung cancer cells}

The results thus far suggested a potential paradigm of NF $-\kappa \mathrm{B}$ activation by ERK8. However, whether similar phenomenon occurs in other cells would need to be verified. As our team has been focusing on lung-related disease, especially lung cancers; for this reason, we screened the basal levels of ERK8 in several human lung cancer cell lines available in our laboratory, including Calu-3, H1299, H358, and H460, by quantitative realtime RT-PCR and western blot analyses. From the
A

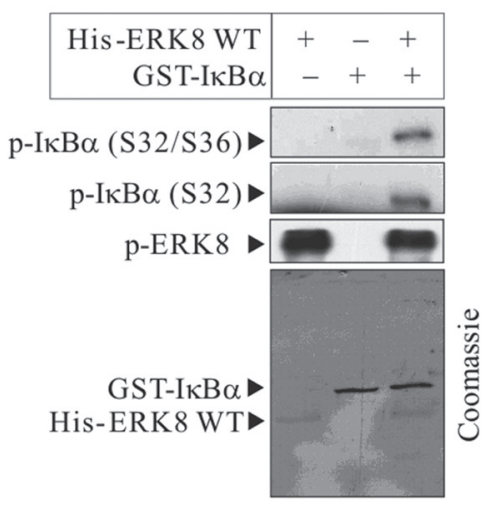

C

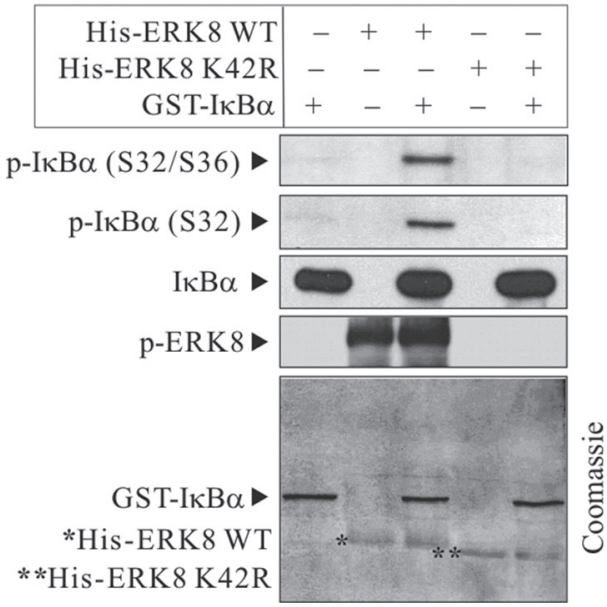

B

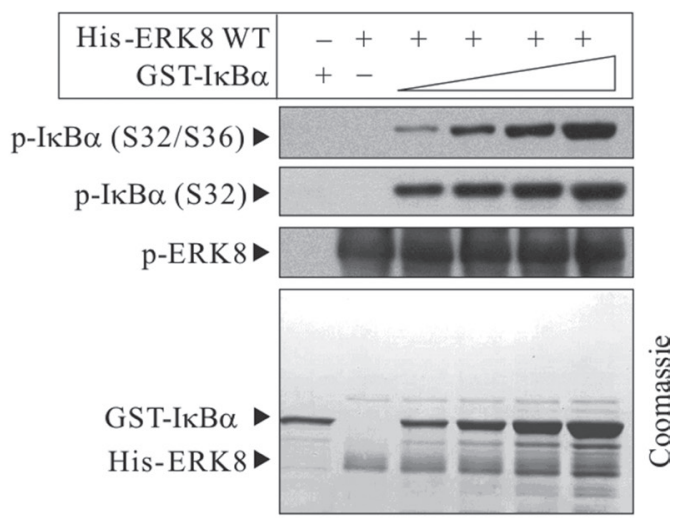

$\mathbf{D}$

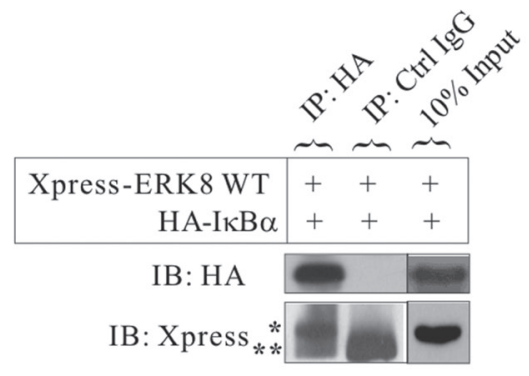

Figure 2: ERK8 phosphorylates and interacts with IKB $\boldsymbol{\alpha}$. In vitro kinase assays were conducted using (A) recombinant active His-

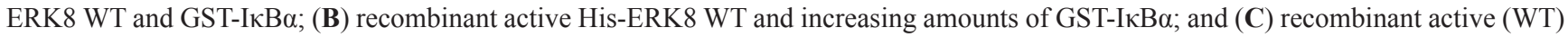

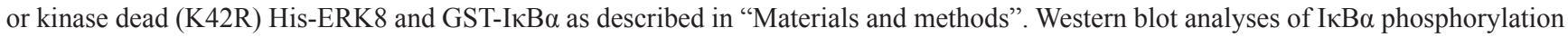
after the kinase assays using phospho-specific antibody against $\mathrm{p}-\mathrm{I} \kappa \mathrm{B} \alpha\left(\mathrm{Ser}^{32}\right)$ or $\mathrm{p}-\mathrm{I} \kappa \mathrm{B} \alpha\left(\mathrm{Ser}^{32} / \mathrm{Ser}^{36}\right)$ were conducted. $\mathrm{p}$-ERK8 levels signifies its kinase activity which could be detected in active His-ERK8 WT but not the ERK8 K42R mutant. (D) Xpress-ERK8 WT and HA-I $\mathrm{B} \alpha \alpha$ expression plasmids ( $3 \mu \mathrm{g}$ of each) were transiently transfected into HEK293T cells. At $24 \mathrm{~h}$ post-transfection, they were cultured in serum-free medium for $24 \mathrm{~h}$, after which they were exposed to $10 \mu \mathrm{M} \mathrm{MG} 132$ for $4 \mathrm{~h}$. IкB $\alpha$ was immunoprecipitated (IP) with anti-HA or Ctrl IgG agarose beads followed by immunoblotting with anti-HA or anti-Xpress antibodies (*, Xpress-ERK8 WT; **, IgG heavy chain). For (A), (B), and (C), the corresponding gels are stained with Coomassie Blue to monitor equal protein loading (bottom panels of each). In (C), *, His-ERK8 WT; **, His-ERK8 K42R). The data are representative of three independent experiments. 
results, it can be seen that ERK8 is expressed at low level in Calu-3 cells; however, among the lung cancer cells, ERK8 has a relatively high expression in H1299, H358, and H460 cells (Supplementary Figure 1A and $1 \mathrm{~B})$. To determine whether there is NF- $\kappa \mathrm{B}$ activation in high ERK8 expressing cells, we checked on H1299 cells since the subcellular fractionation quality turns out to be the best among these cell lines. So, after we treated $\mathrm{H} 1299$ cells with $5 \mu \mathrm{M} \mathrm{As}_{2} \mathrm{O}_{3}$, we fractionated individual subcellular components and it was found that the levels of nuclear NF- $\mathrm{KB}$ in nuclear-soluble and chromatinbound fractions increased as compared with untreated control (Figure 4A). Similar results were observed in H358 cells (data not shown). This indicates that there is an enhanced NF- $\kappa \mathrm{B}$ chromatin-binding in $\mathrm{As}_{2} \mathrm{O}_{3}$ treated cells, and suggests that $\mathrm{NF}-\kappa \mathrm{B}$ might likely be involved in modulating the subsequent gene expressions. To further strengthen the relationship of $\mathrm{As}_{2} \mathrm{O}_{3}$-ERK8I $\kappa \mathrm{B} \alpha-\mathrm{NF}-\kappa \mathrm{B}$ cascade, we generate H1299 stable ERK8 knockdown cells and examine the levels of $\mathrm{p}-\mathrm{I} \kappa \mathrm{B} \alpha$ and I $\kappa \mathrm{B} \alpha$ upon $\mathrm{As}_{2} \mathrm{O}_{3}$ treatment. From our results, knocking down ERK8 in H1299 cells blunted the phosphorylation and degradation of $\mathrm{I} \kappa \mathrm{B} \alpha$ (compare lane 3 to lane 4 in Figure 4B), and as a result sustained the ratio of $\mathrm{p}-\mathrm{I} \kappa \mathrm{B} \alpha /$ I $\kappa \mathrm{B} \alpha$ close to untreated controls. Furthermore, we also performed NF- $\kappa \mathrm{B}$ luciferase assay by transfecting the $5 \times \kappa \mathrm{B}$ firefly luciferase reporter in these shMock and shERK8 cells and then challenged the cells with $5 \mu \mathrm{M}$ $\mathrm{As}_{2} \mathrm{O}_{3}$. Our results indicate that the NF- $\kappa \mathrm{B}$ luciferase activity is significantly suppressed in ERK8 knockdown cells as compared to shMock control (Figure 4C). In addition, the mRNA level of NF- $\kappa \mathrm{B}$ downstream genes Fas $[23,24]$ was detected to further confirm the activation of NF- $\kappa \mathrm{B}$. Interestingly, the expression of Fas increased in shMock but not in stable shERK8 H1299 cells upon exposure to $\mathrm{As}_{2} \mathrm{O}_{3}$ (Figure 4D). These results suggest that ERK8 is critical in mediating the effect of $\mathrm{As}_{2} \mathrm{O}_{3}$ and the subsequent NF- $\kappa \mathrm{B}$ activation in these cells.
A

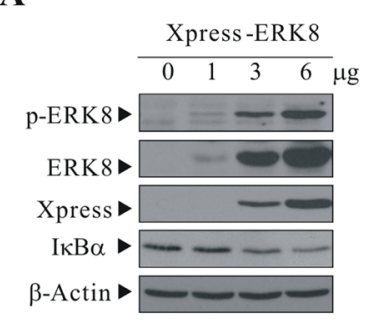

B

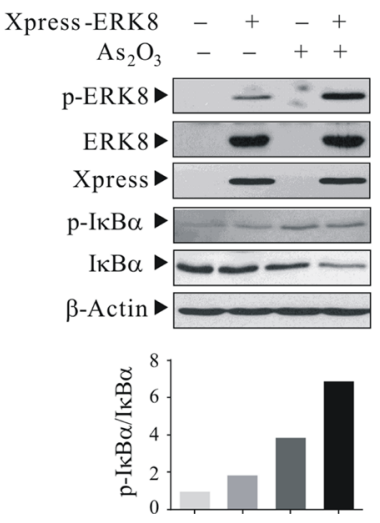

C

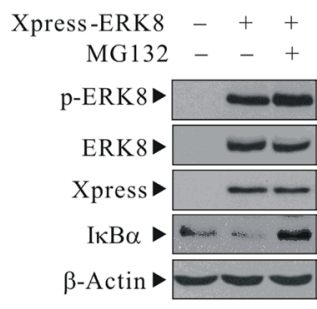

D

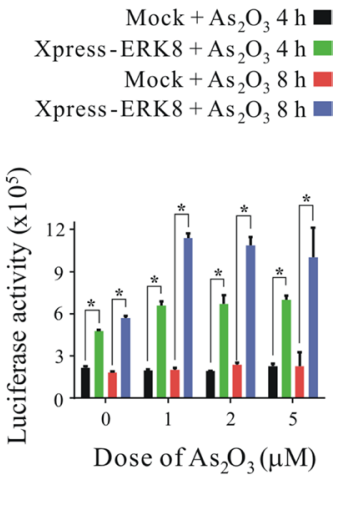

Figure 3: ERK8 promotes the phosphorylation and degradation of IкB $\boldsymbol{\alpha}$. HEK293T cells were transfected with Xpress-ERK8 expression plasmid. At $24 \mathrm{~h}$ post-transfection, they were cultured in serum-free medium for $24 \mathrm{~h}$, after which they were exposed to $5 \mu \mathrm{M}$ $\mathrm{As}_{2} \mathrm{O}_{3}$ for $4 \mathrm{~h}$. (A) cells transfected with 1 to $6 \mu \mathrm{g}$ Xpress-ERK8 expression plasmid; (B) cells transfected with $6 \mu \mathrm{g}$ Xpress-ERK8 expression plasmid; (C) cells transfected with $6 \mu \mathrm{g}$ Xpress-ERK8 expression plasmid, and prior to $\mathrm{As}_{2} \mathrm{O}_{3}$ treatment, cells were first pretreated with $10 \mu \mathrm{M}$ MG132 for $4 \mathrm{~h}$. Cells were lysed, and protein extracts were subjected to SDS-PAGE followed by immunobloting using antibodies against p-ERK8 and p-IкB $\alpha\left(\mathrm{Ser}^{32} / \mathrm{Ser}^{36}\right)$. After development, the membranes were stripped and reprobed with regular antibodies against ERK8, Xpress, I $\kappa \mathrm{B} \alpha$, and $\beta$-actin to monitor the total level of ERK8, I $\mathrm{B} \alpha$ and loading difference, respectively. The intensities of the bands of $\mathrm{p}-\mathrm{I} \kappa \mathrm{B} \alpha$ and $\mathrm{I} \kappa \mathrm{B} \alpha$ in (B) were quantified and expressed as relative ratios, setting 1 for control. (D) NF- $\kappa \mathrm{B}$ luciferase assay using NIH/3T3 cells treated with $\mathrm{As}_{2} \mathrm{O}_{3}$. NIH/3T3 cells seeded at $6 \mathrm{~cm}$ dish were transient transfected with ERK8 expressing plasmid (6 $\left.\mu \mathrm{g}\right)$ along with the $5 \times \mathrm{kB}$ luciferase reporter plasmid $(6 \mu \mathrm{g})$ and the Renilla luciferase reporter plasmid $(150 \mathrm{ng})$. At $24 \mathrm{~h}$ post-transfection, they were seeded into 24 well-plate at $1 \times 10^{5}$ cells/well. After $24 \mathrm{~h}$, they were sham-exposed or exposed to 1,2 , or $5 \mu \mathrm{M} \mathrm{As}_{2} \mathrm{O}_{3}$ for additional 4 and $8 \mathrm{~h}$. NF- $\mathrm{BB}$-luciferase activity was measured and normalized against Renilla luciferase activity as described in "Materials and methods". *A significant difference of $P<0.05$. The data are representative of three independent experiments. 


\section{$\mathrm{As}_{2} \mathrm{O}_{3}$ promotes cell death in high ERK8- expressing lung cancers}

From the above sections, we observed the activation of ERK8 by $\mathrm{As}_{2} \mathrm{O}_{3}$ treatment, with the concomitant phosphorylation and degradation of $\mathrm{I} \kappa \mathrm{B} \alpha$, as well as induction of NF- $\mathrm{KB}$ activity, but whether this would ultimately impact on cell growth or cell death regulation is unclear. For this reason, we sought to study the phenotype of cells mediated by this regulatory circuit. As mentioned earlier, since there is a relatively high ERK8 expression in H1299 cells, we would therefore want to know the outcome of $\mathrm{As}_{2} \mathrm{O}_{3}$ treatment to this high ERK8-expressing lung cancer cell line. H1299 cells were sham-exposed or
A
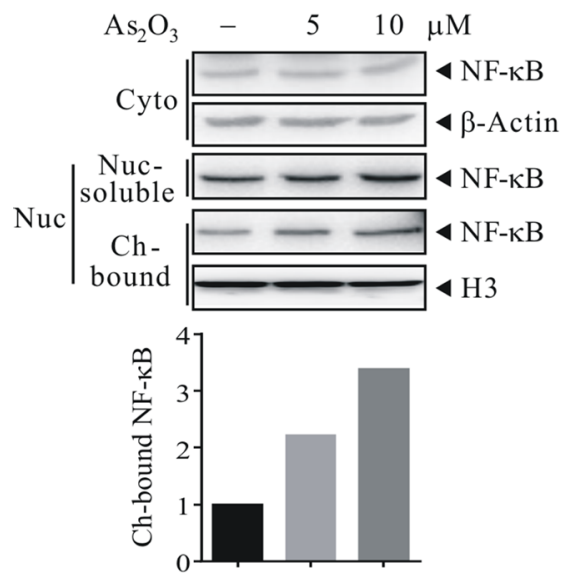

C
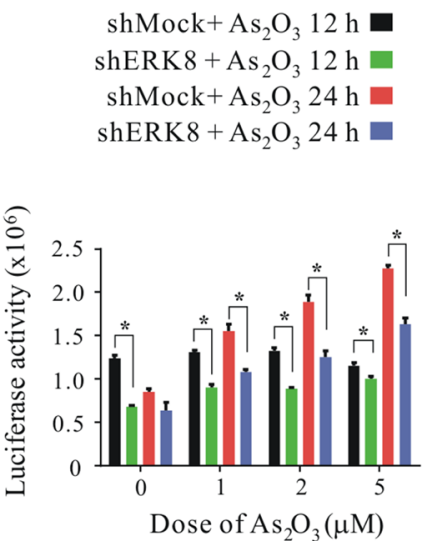

B
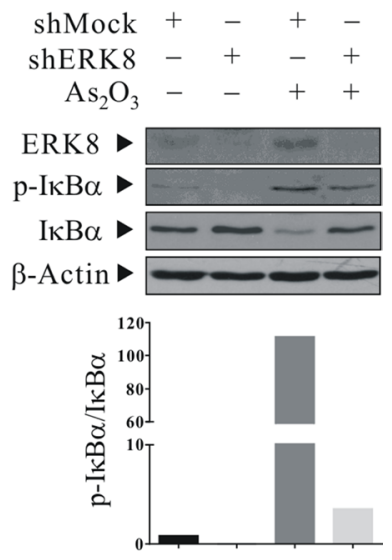

D

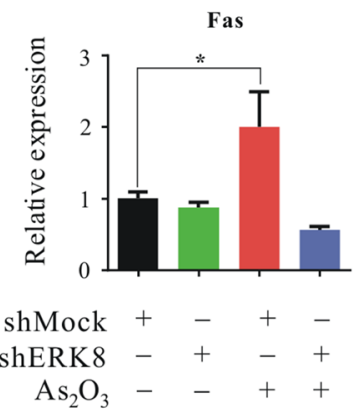

Figure 4: ERK8 promotes the phosphorylation and degradation of IкB $\alpha$, as well as nuclear translocation of NF- $\kappa B$ in human lung cancer cells. (A) $\mathrm{H} 1299$ cells were treated with $5 \mu \mathrm{M} \mathrm{As}_{2} \mathrm{O}_{3}$ for 4 h; individual subcellular fractions (cytoplasmic, nuclear-soluble, and chromatin-bound) were isolated and subjected to western blot analysis using NF-kB p65 antibody. The same blot was stripped and reprobed with the monoclonal $\beta$-actin or histone $\mathrm{H} 3$ antibody to monitor the loading difference. The intensities of the bands of chromatin-bound NF- $\mathrm{KB}$ and histone $\mathrm{H} 3$ were quantified and expressed as relative ratios, setting 1 for control. (B) Stable mock control (shMock) and ERK8 knockdown (shERK8) H1299 cells were cultured in serum-free medium for $24 \mathrm{~h}$, after which they were exposed to $5 \mu \mathrm{M} \mathrm{As}_{2} \mathrm{O}_{3}$ for $4 \mathrm{~h}$. Cells were lysed, and protein extracts were subjected to SDS-PAGE followed by immunobloting using antibodies against ERK8 and $\mathrm{p}-\mathrm{I} \mathrm{KB} \alpha\left(\mathrm{Ser}^{32} / \mathrm{Ser}^{36}\right)$. After development, the membranes were stripped and reprobed with regular antibodies against

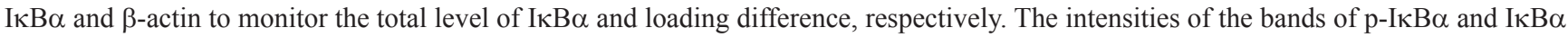
were quantified and expressed as relative ratios, setting 1 for control. (C) NF-kB luciferase assay using shMock and shERK8 H1299 cells treated with $\mathrm{As}_{2} \mathrm{O}_{3}$. Stable shMock and shERK8 $\mathrm{H} 1299$ cells at $6 \mathrm{~cm}$ dish were transient transfected with the $5 \times \mathrm{kB}$ luciferase reporter plasmid $(6 \mu \mathrm{g})$ and the Renilla luciferase reporter plasmid $(150 \mathrm{ng})$. At $24 \mathrm{~h}$ post-transfection, they were seeded into 24 well-plate at $1 \times 10^{5}$ cells/well. After $24 \mathrm{~h}$, they were sham-exposed or exposed to 1,2 , or $5 \mu \mathrm{M} \mathrm{As}_{2} \mathrm{O}_{3}$ for additional 12 and $24 \mathrm{~h}$. NF-kB-luciferase activity was measured and normalized against Renilla luciferase activity as described in "Materials and methods". (D) Quantitative real-time RT-PCR to determine the mRNA level of NF-KB downstream gene Fas in stable shMock and shERK8 H1299 cells treated with $5 \mu \mathrm{M} \mathrm{As}_{2} \mathrm{O}_{3}$ after serum starvation for $24 \mathrm{~h}$. $\beta$-Actin was used as an internal control. *A significant difference of $P<0.05$. The data are representative of three independent experiments. 
treated with $\mathrm{As}_{2} \mathrm{O}_{3}$ (5 to $20 \mu \mathrm{M}$ ) and monitored, it can be seen that massive cytotoxicity occurred in a dose- and time-dependent manner in this cell line (Figure 5A). To check whether the observed cytotoxicity is due to the execution of apoptosis, we checked the expression levels of several important apoptosis mediators by western blot analysis. The induction/cleavage of BAX/CASP9/CASP3 can well be observed (Figure 5B), suggesting that $\mathrm{As}_{2} \mathrm{O}_{3}$ treatment indeed leads to apoptotic cell death. As a proof of concept, we perform similar experiments on shMock and shERK8 H1299 cells. This time, the cell viabilities were monitored by MTS assay post $48 \mathrm{~h}$ of $\mathrm{As}_{2} \mathrm{O}_{3}$ treatment. Notably, knocking down ERK8 in H1299 cells sustained the cell viability of shERK8 cells upon $\mathrm{As}_{2} \mathrm{O}_{3}$ treatment, but not in shMock cells (Figure 5C). Similar results were observed in H460 cells (data not shown). In addition, knocking down ERK8 in H1299 cells blunted the induction/cleavage of marker proteins involved in apoptosis (Figure 5D).

\section{NF-KB specific inhibitor, JSH-23, inhibits ERK8 promoted $\mathrm{As}_{2} \mathrm{O}_{3}$-induced lung cancer cell death}

To further confirm that ERK8 promotes $\mathrm{As}_{2} \mathrm{O}_{3}$-induced lung cancer cell apoptosis mainly and specifically through

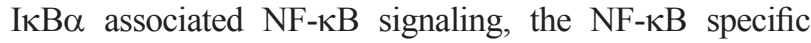
inhibitor (JSH-23) was employed. First, NF- $\kappa \mathrm{B}$ luciferase assay was performed to detect the effectiveness of JSH-23 on the suppression of NF- $\kappa \mathrm{B}$ activity. As we can see in Figure 6A, JSH-23 treatment significantly suppressed $\mathrm{As}_{2} \mathrm{O}_{3}$-induced $\mathrm{NF}-\kappa \mathrm{B}$ luciferase activity in $\mathrm{H} 1299$ cells. To correlate the sensitivity of $\mathrm{H} 1299$ cells to $\mathrm{As}_{2} \mathrm{O}_{3}$ is due to ERK8 mediated $\mathrm{NF}-\kappa \mathrm{B}$ activation, we performed cell viability assay in stable shMock and shERK8 H1299 cells. As expected, JSH-23 treatment significantly sustained the cell viability of $\mathrm{As}_{2} \mathrm{O}_{3}-$ treated shMock H1299 cells (compare column 3 to column 4 in Figure 6B). In the previous section, since we showed that knocking down ERK8 significantly suppressed the NF- $\kappa \mathrm{B}$ activity and sustained the cell viability of shERK8 H1299 cells upon $\mathrm{As}_{2} \mathrm{O}_{3}$ treatment (Figures $4 \mathrm{C}$ and 5C), therefore, no significant difference in $\mathrm{As}_{2} \mathrm{O}_{3}$ sensitivity was observed at all between JSH-23-untreated or JSH-23-treated shERK8 H1299 cells (compare column 7 to column 8 in Figure 6B). These data indicate that lowering the ERK8 level alone is sufficient and reminiscent to reducing the activity of $\mathrm{NF}-\kappa \mathrm{B}$ signaling, which ultimately diminished the cellular sensitivity to $\mathrm{As}_{2} \mathrm{O}_{3}$. Altogether, our data suggest that $\mathrm{As}_{2} \mathrm{O}_{3}$ is very effective in promoting cell death regulation in high ERK8-expressing lung cancer cells and we document for the first time on the interplay of $\mathrm{As}_{2} \mathrm{O}_{3}$-ERK8-I $\kappa \mathrm{B} \alpha-\mathrm{NF}-\kappa \mathrm{B}$ signaling axis.

\section{DISCUSSION}

Our group has been investigating novel functions of protein post-translational modifications. In the present study, we focused on novel substrates of ERK8. Previously, it has been reported that ERK8 is overexpressed in human colon cancers [8], suggesting that ERK8 might be a promising chemotherapeutic target. Here, we first wonder whether ERK8 may be overexpressed as well in lung cancers. For this reason, we screened the levels of ERK8 in several human lung cancer cell lines available in our lab, including Calu-3, H1299, H358, and H460, by quantitative real-time RT-PCR and western blot analyses. From the results, it can be seen that ERK8 is expressed at low level in Calu-3 cells. However, among the lung cancer cells, ERK8 has a relatively high expression in H1299, H358, and H460 cells (Supplementary Figure 1A and 1B).

The traditional Chinese medicine $\mathrm{As}_{2} \mathrm{O}_{3}$ is a wellknown anti-cancer therapeutic agent with promising efficacy on hematologic malignancies such as APL. Interestingly, we found that $\mathrm{As}_{2} \mathrm{O}_{3}$ induced preferential cytotoxicity in several high ERK8-expressing lung cancer cells (H1299, H358, and H460) (Figure 5; Supplementary Figure 1C). Indeed, the pivotal role of ERK8 that it plays in mediating the effect of $\mathrm{As}_{2} \mathrm{O}_{3}$ has been demonstrated in our study, in which shRNA knockdown of ERK8 or inhibition of NF- $\kappa \mathrm{B}$ activity by JSH-23 treatment blunted the $\mathrm{As}_{2} \mathrm{O}_{3}$ induced NF- $\kappa \mathrm{B}$ activation and cell death in $\mathrm{H} 1299$ cells. Although the phosphorylation of ERK1/2 and p38 MAPK also increased slightly by $\mathrm{As}_{2} \mathrm{O}_{3}$ treatment (Figure 1A and 1B; Supplementary Figure 2), however, the magnitude of ERK8 phosphorylation is significantly higher as compared to those of ERK1/2 and p38 MAPK in all the respective time points and $\mathrm{As}_{2} \mathrm{O}_{3}$ dose examined, suggesting that ERK8 is dominantly activated by $\mathrm{As}_{2} \mathrm{O}_{3}$ in high ERK8 expressing cells (Figure 1A-1C; Supplementary Figure 2). Altogether, these data confirm that the interplay of ERK8$\mathrm{I} \kappa \mathrm{B} \alpha-\mathrm{NF}-\kappa \mathrm{B}$ is critical for mediating the apoptotic signal exerted by $\mathrm{As}_{2} \mathrm{O}_{3}$ (Figure 7).

To date, besides IkappaB kinases and ribosomal S6 kinase $2[25,26]$, other potential kinases on the phosphorylation of $\mathrm{I} \kappa \mathrm{B} \alpha$ at $\mathrm{Ser}^{32}$ and $\mathrm{Ser}^{36}$ is unknown/ understudied. Moreover, knowledge about cellular physiological protein substrate(s) of ERK8 is limited. Previous studies have shown that c-Jun is an ERK8 substrate and related to colon and gastric cancer development $[8,9]$. In here, we show that $\mathrm{As}_{2} \mathrm{O}_{3}$ can specifically promote the activation of ERK8 and the subsequent phosphorylation and degradation of $\mathrm{I} \kappa \mathrm{B} \alpha$, leading to NF- $\mathrm{B}$ activation and inducing cell death in high ERK8 expressing human lung cancer cells. The reason of the Janus-faced role of ERK8 in promotion of cell growth and cell death may be very complex and cell type-dependent. Therefore, similar to JNK/c-Jun axis, depending on the types and magnitude of stimuli, which can either promote cell death or cell transformation; suggesting that although EGF (mitogenic stimulus) or $\mathrm{As}_{2} \mathrm{O}_{3}$ (apoptotic stimulus) can both activate the phosphorylation of ERK8 at $\mathrm{Thr}^{175} / \mathrm{Tyr}^{177}$, however, the relaying downstream targets are crucial in dictating the 
A
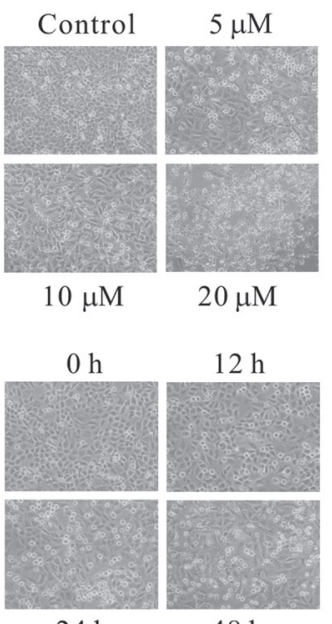

$24 \mathrm{~h}$

C

shMock

- shERK8

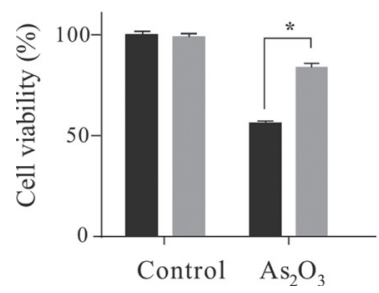

B
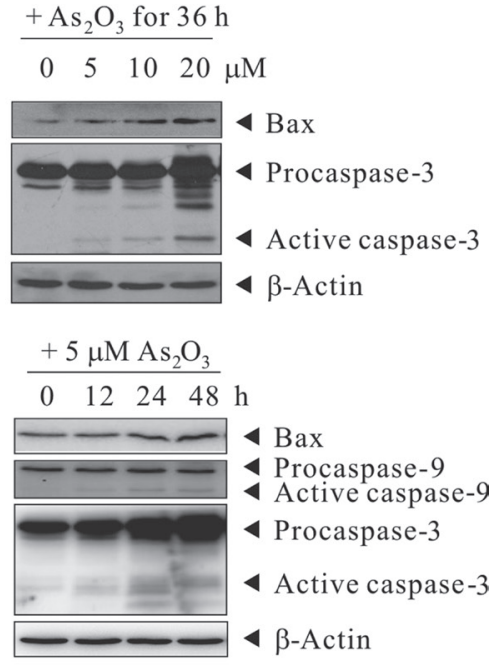

D

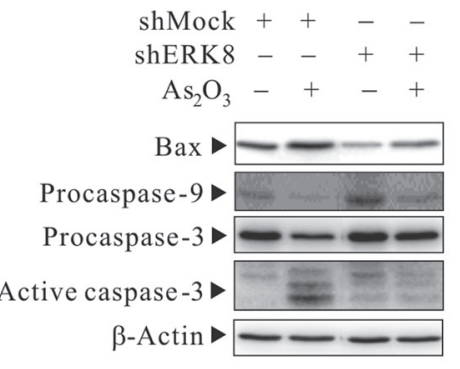

Figure 5: $\mathrm{As}_{2} \mathrm{O}_{3}$ promotes cell death in high ERK8-expressing lung cancers. Dose- and time-dependent cytotoxicity of $\mathrm{As}_{2} \mathrm{O}_{3}$ towards $\mathrm{H} 1299$ cells. $\mathrm{H} 1299$ cells were sham-exposed or exposed to $5-20 \mu \mathrm{M}$ of $\mathrm{As}_{2} \mathrm{O}_{3}$ for $36 \mathrm{~h}$ or $5 \mu \mathrm{M} \mathrm{As}_{2} \mathrm{O}_{3}$ for $12-48 \mathrm{~h}$. (A) cell morphology of H1299 cells under light microscope. (B) The corresponding western blot of (A), cells were lysed and protein extracts were subjected to western blot analyses using antibodies against Bax, Caspase-9, and Caspase-3. After development, the membranes were stripped and reprobed with $\beta$-actin to monitor the loading difference. (C) Stable shMock and shERK8 H1299 cells were sham-exposed or exposed to $5 \mu \mathrm{M} \mathrm{As}_{2} \mathrm{O}_{3}$ for $48 \mathrm{~h}$, the percentage of cell viability was determined by MTS assay. *A significant difference of $P<0.05$. (D) The corresponding western blot of $(\mathrm{C})$ for the determination of marker proteins involved in apoptosis. The data are representative of three independent experiments.

A

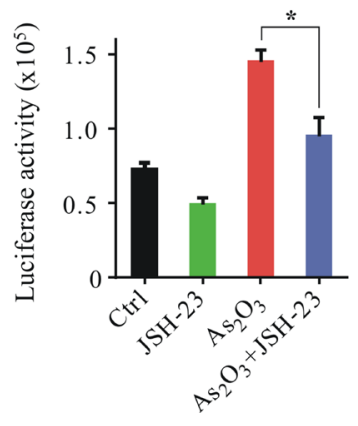

B

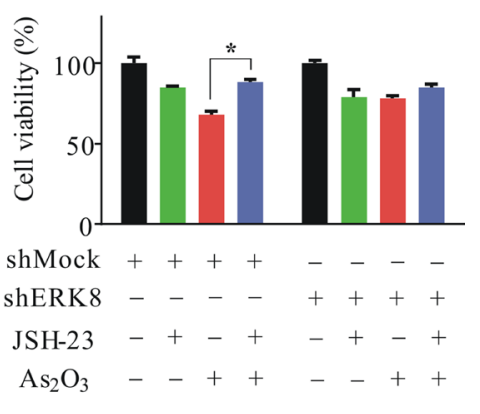

Figure 6: JSH-23 inhibits ERK8 promoted $\mathrm{As}_{2} \mathrm{O}_{3}$-induced lung cancer cell death. (A) NF-kB luciferase assay of $\mathrm{H}_{12} 29$ cells in the presence or absence of JSH-23 $(30 \mu \mathrm{M})$ post $12 \mathrm{~h}$ exposure to $\mathrm{As}_{2} \mathrm{O}_{3}(5 \mu \mathrm{M})$. The NF-kB luciferase activity was determined similarly as described in the previous sections. (B) Stable shMock and shERK8 $\mathrm{H} 1299$ cells were exposed to $\mathrm{As}_{2} \mathrm{O}_{3}(5 \mu \mathrm{M})$ in the presence or absence of JSH-23 $(30 \mu \mathrm{M})$ for $36 \mathrm{~h}$, the cell viability was determined by NBB assay. All the results were expressed as the mean $\pm \mathrm{SD}$ of triplicate samples and the reproducibility was confirmed in three separate experiments. *A significant difference of $P<0.05$. 
cell fate that ultimately lead to cell transformation or cell death. Nevertheless, further study is required to address these issues to find out the NF- $\mathrm{KB}$ dependent genes in response to $\mathrm{As}_{2} \mathrm{O}_{3}$ treatment (besides Fas as we have demonstrated here) that lead to cell death in high ERK8expressing human lung cancer cells.

In summary, we demonstrate for the first time a regulatory paradigm of $\mathrm{NF}-\kappa \mathrm{B}$ activation by ERK8 upon $\mathrm{As}_{2} \mathrm{O}_{3}$ treatment and that $\mathrm{I} \kappa \mathrm{B} \alpha$ is a newly identified cellular physiological substrate of ERK8. Given the important role of ERK 8 in mediating the therapeutic efficacy of $\mathrm{As}_{2} \mathrm{O}_{3}$ against lung cancer cells, we suggest that $\mathrm{As}_{2} \mathrm{O}_{3}$ (besides its promising role in the treatment of hematologic malignancies) as a potential agent in the treatment of lung cancer patients with high ERK8 expression such that this might gain more selective killing of cancer cells. Finally, the work we report here might also implicate the need for ongoing research on the identification and understanding of novel signaling circuit(s) in response to $\mathrm{As}_{2} \mathrm{O}_{3}$ treatment in various cancer types, and hopefully shed light in providing strategies for anti-cancer management.

\section{MATERIALS AND METHODS}

\section{Materials}

Arsenic trioxide $\left(\mathrm{As}_{2} \mathrm{O}_{3}\right)$ and $\mathrm{MG} 132$ were purchased from Sigma-Aldrich (St. Louis, MO). The NF- $\mathrm{B}$ specific inhibitor JSH-23 (S7351) was purchased from Selleck (Shanghai, China). The Subcellular Protein Fractionation Kit for Cultured Cells was from Thermo Scientific (Rockford, IL). shRNAs were purchased from Santa Cruz Biotechnology (Santa Cruz, CA). ERK8 shRNA plasmid (h) (sc-77462-SH) is a target-specific lentiviral vector plasmid encoding a 19-25 nt (plus hairpin) shRNA to knock down gene expression. Control shRNA plasmid-A (sc-108060) encodes a scrambled shRNA sequence that will not lead to the specific degradation of any known cellular mRNA. All other general chemicals were purchased from GE Healthcare (Uppsala, Sweden), Qiagen (Valencia, CA) and Sigma-Aldrich. The pCMV4-3 $\mathrm{HA} / \mathrm{I} \kappa \mathrm{B} \alpha$ (21985) and pRL-SV40P (27163) plasmids were purchased from Addgene (Cambridge, MA). The $5 \times \kappa \mathrm{B}$ luciferase reporter plasmid has been described previously

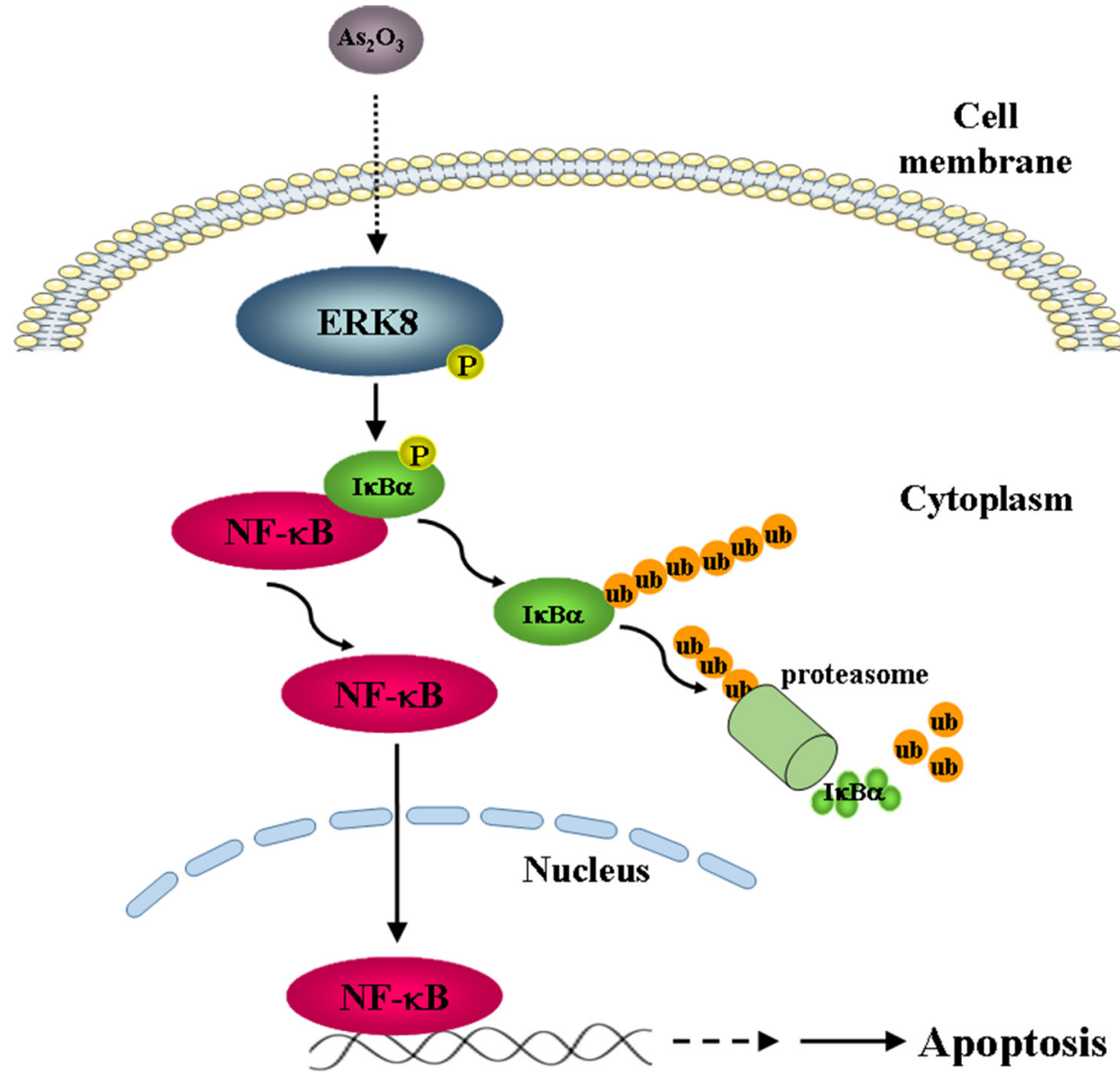

Figure 7: A model of $\mathrm{As}_{2} \mathrm{O}_{3}$ action based on our data is presented. $\mathrm{As}_{2} \mathrm{O}_{3}$ treatment induces the phosphorylation of ERK8 and activated ERK8 subsequently promotes the phosphorylation and degradation of I $\kappa \mathrm{B} \alpha$, which leads to the activation of NF- $\kappa \mathrm{B}$ and lung cancer cell apoptosis. 
[27]. The Homo sapiens ERK8 gene coding sequence (NM_139021) expression plasmid pGEX-2T-GST-ERK8 wild-type (WT) and the corresponding kinase-dead mutant (K42R) were generously provided by Dr. Mark K. Abe from the Univesity of Chicago (Chicago, IL). Antibodies used for western blot were purchased from BBI Life Sciences (Shanghai, China), Santa Cruz Biotechnology, GeneTex (Irvine, CA), Cell Signaling Technology (Danvers, MA), Invitrogen (Waltham, MA) and SigmaAldrich, with the following dilutions: ERK8 (AB21813b; BBI Life Sciences), 1:1000; p-ERK1/2 $\mathrm{Thr}^{202} / \mathrm{Tyr}^{204}$ (4370; Cell Signaling Biotechnology, also being utilized for the detection of phosphorylated ERK8 at $\mathrm{Thr}^{175} / \mathrm{Tyr}^{177}$ as described previously), 1:1000 [8]; ERK1/2 (sc-292838; Santa Cruz Biotechnology), 1:1000; p-p38 MAPK (4511; Cell Signaling Technology), 1:1000; p38 MAPK (8690; Cell Signaling Technology), 1:1000; p-JNK (sc293138; Santa Cruz Biotechnology), 1:1000; JNK (sc7345; Santa Cruz Biotechnology), 1:1000; p-IкB $\alpha$ Ser $^{32}$ (2859; Cell Signaling Biotechnology), 1:1000; p-IкB $\alpha$ $\mathrm{Ser}^{32} / \mathrm{Ser}^{36}$ (9246; Cell Signaling Biotechnology), 1:1000; IкB $\alpha$ (AB20138a; BBI Life Sciences), 1:1000; NF-кB p65 (sc-8008; Santa Cruz Biotechnology), 1:1000; Bax (GTX109683; GeneTex), 1:1000; Caspase-9 (GTX112888; GeneTex), 1:1000; Caspase-3 (GTX110543; GeneTex), 1:1000; HA-probe (sc-7392; Santa Cruz Biotechnology), 1:1000; Xpress (46-0528; Invitrogen), 1:5000; and $\beta$-Actin (A5441; Sigma-Aldrich), 1:10000.

\section{Construction of ERK8 expression plasmids and the corresponding mutants}

The ERK8 WT and ERK8 K42R were each inserted into the pET46 Ek/LIC plasmid and expressed as Histagged fusions as described previously [8]. The ERK8 proteins were purified using Ni-NTA agarose (Qiagen). The ERK8 gene coding sequence was also amplified from pGEX-2T-GST-ERK8 WT by PCR. After restriction digestion, the ERK8 sequence was ligated to the BamHI/ XbaI site of pcDNA4/HisMaxA to generate the pcDNA4/

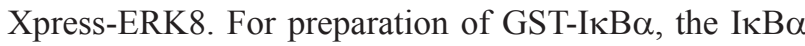
gene coding sequence was amplified from pCMV4-3 $\mathrm{HA} / \mathrm{I} \kappa \mathrm{B}-\mathrm{alph}$ a by PCR. After restriction digestion, the IкB-alpha sequence was ligated to the EcoRI/NotI site of pGEX-5X-1 to generate the pGEX-5X-1/GST- IкB $\alpha$. The recombinant plasmids were confirmed by DNA sequencing (Beijing Genomics Institute, Shenzhen, Guangdong, China).

\section{Cell culture and transfection}

All the cell lines employed in this study, including human lung cancer cells (Calu-3, H1299, H358, and H460) as well as HEK293T, NIH/3T3, HL-60, HepG2, and HeLa cells, were purchased from and authenticated by the ATCC Cell Bank of the Chinese Academy of
Sciences (Shanghai, China) and cultured following the supplier's recommended conditions. Cell viability was measured by MTS or NBB assay as described previously $[8,28]$. Transfection of the expression vectors was performed using Lipofectamine (Invitrogen) following the manufacturer's suggested protocol. For generation of ERK8 knockdown cells, viral particles were packed with control or ERK8 shRNA. H1299 cells, grown to about $70 \%$ confluence, were infected with the above lentiviral shRNAs in the presence of $8 \mu \mathrm{g} / \mathrm{ml}$ polybrene for $24 \mathrm{~h}$. Uninfected cells were eliminated by exposure to $2 \mu \mathrm{g} / \mathrm{ml}$ puromycin for 4 days before use.

\section{Quantitative real-time RT-PCR}

In brief, total RNA was extracted from cells using TRIzol Reagent (Thermo Fisher Scientific, 15596018). cDNA was synthesized using PrimeScript Reverse Transcriptase (Takara, 2680A) according to the manufacturer's instructions. Quantitative real-time RT-PCR was performed with GoTaq qPCR Master Mix (A6001) from Promega (Fitchburg, WI) and gene-specific primers on Applied Biosystems 7500 Real-Time PCR System. $\beta$-Actin was amplified as internal reference to normalize gene expression. Relative expression of genes was calculated using $2 \Delta \Delta C T$ method as described previously [29]. Primers were synthesized by Beijing Genomics Institute with the following sequences: ERK8 (forward: 5'-GACCAGAAGCCGTCCAATGT-3', reverse: 5'-GTATCGGTGCGAAGAGAGCA-3'); Fas (forward: 5'-TGAAGGACATGGCTTAGAAGTG-3', reverse: 5'-GG TGCAAGGGTCACAGTGTT-3') and $\beta$-actin (forward: 5'-ATGGGTCAGAAGGATTCCTATGTG-3', reverse: 5'-CTTCATGAGGTAGTCAGTCAGGTC-3').

\section{Cell lysate preparation and conditions of western blot and immunoprecipitation}

After treatment, cells were then washed thrice with ice-cold PBS, scraped into centrifuge tube, and then harvested by centrifugation at $1000 \times \mathrm{g}$ for $5 \mathrm{~min}$ at $4^{\circ} \mathrm{C}$. For subcellular protein preparation, the cytoplasmic, nuclear-soluble, and chromatin-bound fractions were prepared using the Subcellular Protein Fractionation Kit for Cultured Cells in accordance with the manufacturer. For western blot analysis, cell pellets were lysed in radioimmunoprecipitation assay buffer according to the protocol as described previously [28]. Equal amounts of proteins were fractionated on a SDS-polyacrylamide gel and transferred onto polyvinylidene difluoride membranes. The membranes were blocked with 5\% nonfat dry milk in PBS containing $0.05 \%$ Tween 20 and probed with various primary antibodies. After incubation with secondary antibodies, immunoblots were visualized with the enhanced chemiluminescence detection kit (GE Healthcare). The normalized target band signal intensities 
of one data set among the three independent repeats were expressed as relative ratios and presented as bar graphs. For immunoprecipitation, cells were harvested at 80 to $90 \%$ confluence and proteins were extracted in NP40 cell lysis buffer $[50 \mathrm{mmol} / \mathrm{L}$ Tris- $\mathrm{HCl}(\mathrm{pH}$ 8.0 ), $150 \mathrm{mmol} / \mathrm{L} \mathrm{NaCl}, 0.5 \% \mathrm{NP} 40]$ with freezing and thawing. Equal amounts of proteins were subjected to immunoprecipitation followed by western blot analysis.

\section{In vitro kinase assay}

To detect I $\kappa \mathrm{B} \alpha$ phosphorylation, GST-I $\kappa \mathrm{B} \alpha$ proteins (1 $\mu \mathrm{g})$ were mixed with purified recombinant active or kinase dead His-ERK8, $0.2 \mu \mathrm{M}$ ATP, and $1 \times$ kinase buffer and incubated at $30^{\circ} \mathrm{C}$ for $30 \mathrm{~min}$. The reaction was stopped by adding $5 \times$ SDS sample buffer. The samples were boiled and then separated by SDS-PAGE and visualized by western blot analyses, or Coomassie Blue staining.

\section{Reporter gene assay}

The $5 \times \kappa \mathrm{B}$ luciferase reporter plasmid construct which contains the $5 \times \mathrm{NF}-\kappa \mathrm{B}$ binding site was used. NF$\kappa \mathrm{B}$ activity was analyzed by transfection of the $5 \times \kappa \mathrm{B}$ luciferase reporter plasmid into ERK8-overexpressing or -knockdown cells. Cells were disrupted with lysis buffer (dual-luciferase reporter assay system, Promega) at room temperature for $30 \mathrm{~min}$ by gentle shaking, and then firefly luciferase activity was measured. The NF- $\mathrm{B}$-luciferase activity was normalized against Renilla luciferase activity (pRL-SV40P).

\section{Statistical analysis}

Statistical analysis was done by using two-tailed Student's $t$-test. A $P$ value of $<0.05$ was considered significant. Except for western blot analyses, all other quantitative results were expressed as the mean $\pm \mathrm{SD}$ of triplicate samples. The reproducibility of experimental results was confirmed in three separate experiments and representative data set was shown.

\section{ACKNOWLEDGMENTS AND FUNDING}

This work was supported by the grants from the National Natural Science Foundation of China (Nos. 31271445 and 31170785), the Science and Technology Planning Project of Guangdong Province of China (No. 2016A020215144), the Guangdong Natural Science Foundation of China (No. S2012030006289), "Thousand, hundred, and ten" project of The Department of Education of Guangdong Province (No. 124), and the Department of Education, Guangdong Government under the Toptier University Development Scheme for Research and Control of Infectious Diseases. We would like to thank members of the Lau And Xu laboratory for critical reading of this manuscript.

\section{CONFLICTS OF INTEREST}

The authors declare they have no competing interests.

\section{REFERENCES}

1. Abe MK, Saelzler MP, Espinosa R 3rd, Kahle KT, Hershenson MB, Le Beau MM, Rosner MR. ERK8, a new member of the mitogen-activated protein kinase family. J Biol Chem. 2002; 277:16733-16743.

2. Cargnello M, Roux PP. Activation and function of the MAPKs and their substrates, the MAPK-activated protein kinases. Microbiol Mol Biol Rev. 2011; 75:50-83.

3. Abe MK, Kuo WL, Hershenson MB, Rosner MR. Extracellular signal-regulated kinase 7 (ERK7), a novel ERK with a C-terminal domain that regulates its activity, its cellular localization, and cell growth. Mol Cell Biol. 1999; 19:1301-1312.

4. Klevernic IV, Stafford MJ, Morrice N, Peggie M, Morton S, Cohen P. Characterization of the reversible phosphorylation and activation of ERK8. Biochem J. 2006; 394:365-373.

5. Abe MK, Kahle KT, Saelzler MP, Orth K, Dixon JE, Rosner MR. ERK7 is an autoactivated member of the MAPK family. J Biol Chem. 2001; 276:21272-21279.

6. Iavarone C, Acunzo M, Carlomagno F, Catania A, Melillo RM, Carlomagno SM, Santoro M, Chiariello M. Activation of the Erk8 mitogen-activated protein (MAP) kinase by RET/PTC3, a constitutively active form of the RET proto-oncogene. J Biol Chem. 2006; 281:1056710576.

7. Klevernic IV, Martin NM, Cohen P. Regulation of the activity and expression of ERK 8 by DNA damage. FEBS Lett. 2009; 583:680-684.

8. Xu YM, Zhu F, Cho YY, Carper A, Peng C, Zheng D, Yao K, Lau AT, Zykova TA, Kim HG, Bode AM, Dong Z. Extracellular signal-regulated kinase 8-mediated c-Jun phosphorylation increases tumorigenesis of human colon cancer. Cancer Res. 2010; 70:3218-3227.

9. Jin DH, Lee J, Kim KM, Kim S, Kim DH, Park J. Overexpression of MAPK15 in gastric cancer is associated with copy number gain and contributes to the stability of c-Jun. Oncotarget. 2015; 6:20190-20203. doi: 10.18632/ oncotarget.4171.

10. Groehler AL, Lannigan DA. A chromatin-bound kinase, ERK8, protects genomic integrity by inhibiting HDM2-mediated degradation of the DNA clamp PCNA. J Cell Biol. 2010; 190:575-586.

11. Colecchia D, Strambi A, Sanzone S, Iavarone C, Rossi M, Dall'Armi C, Piccioni F, Verrotti di Pianella A, Chiariello M. MAPK15/ERK8 stimulates autophagy by interacting with LC3 and GABARAP proteins. Autophagy. 2012; 8:1724-1740.

12. Murgo AJ. Clinical trials of arsenic trioxide in hematologic and solid tumors: overview of the National Cancer 
Institute Cooperative Research and Development Studies. Oncologist. 2001; 6:22-28.

13. Miller WH Jr, Schipper HM, Lee JS, Singer J, Waxman S. Mechanisms of action of arsenic trioxide. Cancer Res. 2002; 62:3893-3903.

14. Ferlay J, Soerjomataram I, Ervik M, Dikshit R, Eser S, Mathers C, Rebelo M, Parkin DM, Forman D, Bray, F. GLOBOCAN2012 v1.0, Cancer incidence and mortality worldwide. IARC CancerBase. 2013; 11.

15. Kim ES. Chemotherapy Resistance in Lung Cancer. Adv Exp Med Biol. 2016; 893:189-209.

16. Lam SK, Mak JC, Zheng CY, Li YY, Kwong YL, Ho JC. Downregulation of thymidylate synthase with arsenic trioxide in lung adenocarcinoma. Int J Oncol. 2014; 44:2093-2102.

17. Seo SK, Kim JH, Choi HN, Choe TB, Hong SI, Yi JY, Hwang SG, Lee HG, Lee YH, Park IC. Knockdown of TWIST1 enhances arsenic trioxide- and ionizing radiationinduced cell death in lung cancer cells by promoting mitochondrial dysfunction. Biochem Biophys Res Commun. 2014; 449:490-495.

18. Yang MH, Zang YS, Huang H, Chen K, Li B, Sun GY, Zhao XW. Arsenic trioxide exerts anti-lung cancer activity by inhibiting angiogenesis. Curr Cancer Drug Targets. 2014; 14:557-566.

19. Suzuki T, Ishibashi K, Yumoto A, Nishio K, Ogasawara Y. Utilization of arsenic trioxide as a treatment of cisplatinresistant non-small cell lung cancer PC-9/CDDP and PC-14/ CDDP cells. Oncol Lett. 2015; 10:805-809.

20. Chang KJ, Yang MH, Zheng JC, Li B, Nie W. Arsenic trioxide inhibits cancer stem-like cells via down-regulation of Gli1 in lung cancer. Am J Transl Res. 2016; 8:1133-1143.

21. Cheepsattayakorn A, Cheepsattayakorn R. Lung cancer chemotherapy, new treatment and related patents. Recent Pat Anticancer Drug Discov. 2014; 9:372-381.
22. Hayden MS, Ghosh S. Shared principles in NF-kappaB signaling. Cell. 2008; 132:344-362.

23. Chan H, Bartos DP, Owen-Schaub LB. Activationdependent transcriptional regulation of the human Fas promoter requires NF-kappaB p50-p65 recruitment. Mol Cell Biol. 1999;19:2098-2108.

24. Singh NP, Nagarkatti M, Nagarkatti PS. Role of dioxin response element and nuclear factor-kappaB motifs in 2,3,7,8-tetrachlorodibenzo-p-dioxin-mediated regulation of Fas and Fas ligand expression. Mol Pharmacol. 2007;71:145-157.

25. Mercurio F, Zhu H, Murray BW, Shevchenko A, Bennett BL, Li J, Young DB, Barbosa M, Mann M, Manning A, Rao A. IKK-1 and IKK-2: cytokine-activated IkappaB kinases essential for NF-kappaB activation. Science. 1997; 278:860-866.

26. Peng $\mathrm{C}$, Cho YY, Zhu F, Xu YM, Wen W, Ma WY, Bode AM, Dong Z. RSK2 mediates NF-\{kappa $\}$ B activity through the phosphorylation of IkappaBalpha in the TNF-R1 pathway. FASEB J. 2010; 24:3490-3499.

27. Wu X, Qi J, Bradner JE, Xiao G, Chen LF. Bromodomain and extraterminal (BET) protein inhibition suppresses human $\mathrm{T}$ cell leukemia virus 1 (HTLV-1) Tax proteinmediated tumorigenesis by inhibiting nuclear factor $\mathrm{\kappa B}$ (NF-kB) signaling. J Biol Chem. 2013; 288:36094-36105.

28. Xu YM, Zhou Y, Chen DJ, Huang DY, Chiu JF, Lau ATY. Proteomic analysis of cadmium exposure in cultured lung epithelial cells: evidence for oxidative stress-induced cytotoxicity. Toxicol Res. 2013; 2:280-287.

29. Livak KJ, Schmittgen TD. Analysis of relative gene expression data using real-time quantitative PCR and the 2(-Delta Delta C(T)) Method. Methods. 2001; 25:402-408. 